あのとする目的があり，今後検討する答弁があった。 演題205は，骨盤計測撮影ておして，Martius \& Guthmann 撮影台の自動露出機構についてホトタイマの受光 部採光野の位置の検討及び管電圧特性の改善, 補償フィ ルタの試作等を検討している。

今回の発表の中では，203，204席に見られるように， 自動露出単一で検討するのではなく，X線装置の一部之 して発生装置機構そのものを改善する検討がなされてお り，今後の一方向を示していると見られ，より多くの発 表加望まれる。

\section{診断用装置-4 自動露出-2}

座長 日浦康雄（大阪成人病センタ一)

206. 断層撮影用自動露出装置 TDC-2 (Tomographic Density Control) について

関東逓信病院第 2 放射線科

○田中秀昭, 柴田英三郎・小林正敏

若松 修・高毛澧篤子・渡辺一典

〔目的】断層撮影用自動露出装置 TDC-2 は初期電流 を設定し，断層撮影中におけるX線吸収の変化に対して は自動的に管電流汃応答するもので，いわゆる管電流変 化による自動露出制御方式である。今回わ机われは，本 装置を臨床に応用すべく基礎的な実験をおこなったので 報告した。

[結果]，本装置の特性，応答状態を調へた結果，実際 の断層撮影にあたり，被写体に対して適正乙思われる条 件を設定しておけば，ほぼ安定した断層写真が得られる 事が判明し臨㕅に応用した結果濊定な結果を得ている。 また 1 秒以下の直線断層撮影には short time memory 機構が動作し，ほぼ一定な強度の線量が得られ満足な結 果が得られた。以上の事について報告した。

\section{I.I 面マルチ採光方式 $\mathrm{X}$ 線自動露出制御の検討 (第} II 報)

北海道対がん協会検誩センター放射線科

○西本祐仁・斉藤文男・速水宏行

日立メディコ(株)

池田 満・村上文男・岡部哲夫

〔目的】第38回総会におりて，われわれは，I.I. マル チ採光方式による自動露出制御方式による検討結果を報 告した。.今回さらに，被写体厚特性等の改良を行い良好 な結果が得られたので報告する.

[方法] 前回は，腹厚の薄い人は写真濃度が，濃くな る傾向が見られた。そこで今回は，ファントムの薄い方 では，濃度汃低くなるような被写体厚特性を求めた。 又
当施設のX線テレビ装置に ZP-AEC を組み合わせて 120 名の霄部臨床写真をもとに，撮影体位別，腹厚別に写真 濃度を評洒した。

〔結果】各撮影体位につして，良好な結果汃得られた。 また各腹厚に対する写責濃度が，平均化された。

208. マルチチャネル X線自動露出制御装置を使用した 透視撮影台の画質向上の試み

神奈川県予防医学協会

○樋口政昭・萩原 明・武井恒夫 本条八洋・高橋公二・田中耗策 宮下悦代・大屋博宣・滝真理子

日立メディコ

\section{村上文男・池田 満・白木英成}

照X線直接撮影自動露出の問題点已して, 腹所位充盈 像のバリウム被覆による露出過俥，斜位時ハレーション による露出不足がある。最近発表されたI・I面マルチ採 光方式による自動露出機構 ZP-AEC を用して，6 万月 2,000 名のルチン写真評価を行ない, 各チャネルのレべ ル調整て役立てた。露出不足を生じ易け骨形，体位別の 至適撮影電瓜について調へ，不適写真の割合を $0.4 \%$ 亿 減らすととができた：さらに，管球の A-K 位置の逆転， 照射野を四つ切以下に固定, ウェッデフィルタの試作な よ゙の画質向上対策を行なって，完全自動露出による，比 較的均等濃度の写真を得るととができた。

209. 造影剂被覆補正を加えた消化管撮影における自動 露出

島津製作所知用技術部

○土井泰敬・橋詰辰夫・片山智史

消化管撮影X線テレビ装置の白動露出につき過去本総 会て打して報告した。

今回，動作原理が全く同しで，その構成が非常に簡単 な方法を実施して，結果が良好であるので報告する。

とれは，速写撮影直前の透視状態に扮いて，I・I出力 の採光野内の輝度を検出し, 增巾, 保持して, 続いて実 施される撮影に対するホトタイマのフィルム濃度設定基 準值とするものである。

との簡単な方法によって，被覆に対する補正はほぼ完 全におしなわれ，従来の撮影時における手動による補正 は不要になると考える。

210. 断層撮影用自動露出機構の試作（第二報） 東邦大学医学部付属大森病院中央放射線部 ○石井伴明 - 加藤郁夫 南波哲朗・泉・重光 島津製作所医用機器事業部 
北村満昭・駒井徳蔵

われわれの試作した回路は，ROM 記憶方式というも のて, 初期選択管電在でとの, 蛍光量と適正管電圧のデ 一夕を, ROM に記憶させ，撮影時に初回撮影管電圧值 と，その時の蛍光量值より，適正管電圧を㭔び出し，次 回の撮影管電圧しする方式である。全面および各種分割 撮影に対応をせるため, 円形及びハの字形採光野を有す, 受光部を試作し検討した。試作装置は良好に動作し，わ 㧈われの信頼も高く，検查時間の大幅な短縮に，貢献し ている.初圂より自動露出させる方法として,テトロー ドチューブを用い，撮影開始後，極短時間内に监光量測 定により. 適正管電庄を求め, 瞬時に修正する方式が, 今後の多目的断層用自動露出機構として, 有効であると 考えら杭る。

\section{座長集約}

との演題群は

1) 断層用自動露出

2) マルチチャンネル採光方式による検討

3) 造影剂による被覆補正の検討

に大別できる.

1）行該当する演題は206席，210席で，206席の方法は 撮影中に濃度の調整をおとなうものであらかじめ管電圧， 撮影時間および初期電流值を設定し，撮影中に主に管電 流の変化による濃度調整を行うものである。しかしとの 万式は，写真濃度に奇与しなし部分の出力を増し，濃度 か付き易い部分の出力を抑える結果と成り，被曝線量お よび障嗐陰影の增加を招く結果になるのではないか（阪 大・中西氏質問）との疑念ああるか，本装置では short time memory の機構があり，1秒以下の撮影では，ほ ぼ 3 回目以下では安定した電流と成り，一応撮影回数の

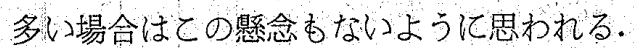

一方演題 $210 は ，$ 受光部に改良を加えて 2 チャンネル 方式に成っているが，第一回目の撮影によって濃度の判 定を下し，2回目以下からの撮影に適正露出を与えよう とするもので，1回目が test shot 的な撮影であるため 患者への被儤線量軽娍等任問題がある.

また，受光部の取り付け位置に寸法的に制限があり， 2 チャンネル方式にするも，機能を充分に発揮できない 所むある、装置の改良等, 今後検討する余地がある。

2）飞該当する演題は，207席，208席で，双方共自動露 出 (ZP-AEC) を使用し，自動露出の問題点として，バ リウム被覆, ハレーションによる露出不足等の補正の改 良を加え，臨床写真を元に，5段階評価を加え検討して やる。改良後，ほほ思わくの写真が得られているように
思われる。

3）飞相当する演題は209席で，消化管撮影における自 動露出では，十の補正と一の補正（食道撮影等）があり 必要に応じて，切り換えられるのか（神奈川成人病セン ター松田氏質問）問題があるが，現時点では，被覆に詨 する補正のみで，高輝度の補正を完全にするのは不可能 である。採光野の形，および位置を考慮中で，乙れは今 後改良を加える必要がある。

また $100 \%$ 被覆された場合です，濃度がおさえられて いるのは (東芝・青木氏質問)，散乱線等により,フォト 信号にかなりの出力が見られたためである.

また増影剤で被覆された場合でも完全に同一濃度にす るのは，臨床的に良し写真かどうか(東芝・青术氏質問） は，まだ，臨床的に確認をとっておらず，今後の課題で ある.

X線装置の自動化が進む中て，より完全な自動化を望 むならば，完全な自動露出の出現なくして，真の自動化 はあり得なりといっても過言ではないと思う。合後の研 鑚を望みます。

\section{診断用装置 $-\mathbf{5}$}

\section{座長 新開英秀 (九州大学)}

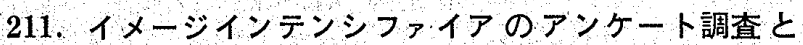
変換係数の簡便測定法

$$
\begin{aligned}
& \text { 名古屋大学医潦技術短期大学部 } \\
& \text { 診療放射線技術学科 } \\
& \text { ○橋本幹男 - 前越 久- 津坂昌利 } \\
& \text { 名古屋大学医学部附属病院放射線部 }
\end{aligned}
$$
近藤智昭

1982年 3 月イメーシインテンシファイア (I. I.) のJIS 規格が制定された。以前われわれは，I.I. 使用年数およ び透視条件のアンケート調查を行った. そしてそれをむ 之に，JIS 規格による変換係数測定と，使用者側で測定 する簡便法を比較検討し，簡便法によるIＩ．．劣化，経年 変化追跡の可能性を考察した。調查結果は，透視条件 80 $\sim 100 \mathrm{kV}, 1 \mathrm{~mA}$ の範囲を越えるもの $50 \%, 3$ 年以上使 用のものが半数を占めた。 簡便法は, 光学系レンズを通 して, $80 \mathrm{kV} \mathrm{X}$ 線で行いJIS 規格の方法と比へて変換 係数は，66\%を得た. しかし経年変化，劣化のチェック には十分使えた. 2480 時間使用の I.I.では被曝線量は， 変換係数から3倍になっているすのと推定された。

\footnotetext{
212. ヘイコントラストイメージアンプリファイアの消 化器診断への適用
} 